Article

\title{
Participation of Brinjal Farmers in Large and Small Wholesale Markets: Factors Influencing Farmers' Decisions and Impact on Producers' Prices
}

\author{
Masud Rana ${ }^{1,2, *}$ and Keshav Lall Maharjan ${ }^{3}$ (1) \\ 1 Graduate School for International Development and Cooperation, Hiroshima University, \\ Higashi-Hiroshima 739-8529, Hiroshima, Japan \\ 2 Department of Agricultural Marketing, Ministry of Agriculture, Dhaka 1215, Bangladesh \\ 3 International Economic Development Program, Graduate School of Humanities and Social Sciences, \\ Hiroshima University, Higashi-Hiroshima 739-8529, Hiroshima, Japan; mkeshav@hiroshima-u.ac.jp \\ * Correspondence: adpp2@dam.gov.bd or masudrana325@gmail.com; Tel.: +88-01736-125546
}

check for updates

Citation: Rana, M.; Maharjan, K.L. Participation of Brinjal Farmers in Large and Small Wholesale Markets: Factors Influencing Farmers'

Decisions and Impact on Producers Prices. Sustainability 2022, 14, 2357. https://doi.org/10.3390/su14042357

Academic Editor: Julio Berbel

Received: 8 January 2022

Accepted: 14 February 2022

Published: 18 February 2022

Publisher's Note: MDPI stays neutral with regard to jurisdictional claims in published maps and institutional affiliations.

Copyright: (C) 2022 by the authors. Licensee MDPI, Basel, Switzerland. This article is an open access article distributed under the terms and conditions of the Creative Commons Attribution (CC BY) license (https:/ / creativecommons.org/licenses/by/ $4.0 /)$.

\begin{abstract}
This research aims to explore the factors associated with the decisions of brinjal (aubergine) farmers to participate in large wholesale markets and estimate the impact of large wholesale markets participation on producers' prices in the Jashore and Narsingdi districts of Bangladesh. A linear probability model (LPM) was used to identify the factors associated with decisions to participate in large wholesale markets, and propensity score matching (PSM) was applied to estimate the impact of large wholesale markets on producer prices. The results showed that the decision to participate in a large wholesale market is significantly associated with years of schooling, farm size, the distance from the farm to the large wholesale market, road quality from the farm to the market, access to extension services, market information, group marketing, trust-based credit, yield, and transportation cost. Moreover, this study consistently showed that participation in a large wholesale market had a positive effect on producer price. Therefore, this study suggests the policy implication that comprehensive strategies must be adopted by the government to increase small-scale farmers' participation in large wholesale markets and improve the welfare of these farmers.
\end{abstract}

Keywords: brinjal; Bangladesh; linear probability model; PSM; large wholesale market; comprehensive strategies; trust-based credit

\section{Introduction}

The instability of growers' prices is a central reason for their unstable income [1] and has been a challenge for farmers [2] as well as agricultural policy makers over the years in developing countries [1]. Understanding the dynamics [3] of market participation, the ability of farmers to participate in a market effectively and efficiently [4] can facilitate an exploration of the market's potential [3] to obtain better prices for farmers. Sustained price-stabilization mechanisms [1] for farmers are a key policy tool to make agriculture sustainable in a developing country such as Bangladesh by means of improving the income and food security of the nation [5]. Bangladesh is committed to doubling the agricultural productivity and income of small-scale food producers, as defined at the 2030 Agenda for Sustainable Development Goals 2.3 [6]. In order to maximize the benefits that farmers earn, farmers must make an appropriate decision as to where they should sell their product [7]. Generally, to ensure income from their harvests, farmers depend on traders, temporary roadside markets, and nearby markets. However, accessing better prices depends on the choice of market and sales channels. Thus, market participation and the subsequent choice of market is a major gateway to raising the income, reducing the poverty, and improving the general welfare of farmers [5,8]. This paper examines the factors influencing brinjal (aubergine) farmers' decisions regarding large wholesale market participation and 
estimates the impact of large wholesale market participation on producers' prices in the Jashore and Narsingdi districts of Bangladesh.

There are two types of determinants for the market participation of smallholders as well as commercial farmers, namely, external and internal factors. The external factors that influence the market participation of farmers include the existing physical and institutional infrastructure such as roads, electricity, transport systems, communication, markets, and the rules of the law [4]. On the other hand, farm size, experience, capital, schooling, asset ownership, human skill, and the utilization of market information are the internal factors that affect market participation. In addition, many studies [9-15] argued that socioeconomic factors, physical factors, institutional factors, and marketing factors are pivotal in the determination of market participation. Socioeconomic factors such as age, gender, household size, source of labor, farming experience, farm size, and volume of production can positively affect market participation decisions among smallholder farmers and subsequently increase the level of participation [11,16-19]. Furthermore, the availability of physical and market infrastructure, access to equipment, and the positive attitude of the head of the household towards risk significantly affect the decision of a household to participate in the market [20]. Moreover, Sizibia et al. [21] identified that not only institutional factors, such as public assets, extension services, and price information, but also market factors, such as the distance to the market and the road networks, are crucial for market participation decisions. In addition, Kyaw et al. [5] found that the transportation of goods from rural areas to urban areas influenced market participation by smallholder rice farmers in Myanmar due to better road conditions.

Approximately 142 types of vegetables are grown in Bangladesh in both the summer and winter seasons, some even all year round [22]. Brinjal (known as aubergine in many parts of the world) is the second most important vegetable in Bangladesh in terms of both production area and yield, and is a popular source of income for small and marginal farmers, only surpassed by potatoes [23]. In 2019, 82 thousand acres were used for brinjal (aubergine) cultivation, with a production of 530 thousand metric tons [24]. Brinjal (aubergine) enters the marketing chain immediately after harvesting. Farmers normally harvest two to three times a week during the harvesting season [23]. Therefore, brinjal (aubergine) is an important source of income for small-scale, poor Bangladeshi farmers. Vegetables are perishable in nature and cannot be stored for long periods, which necessitates their immediate sale after harvesting [25]. However, the prices offered by producers vary according to the nature of market in which the product is sold. Therefore, farmers income depends on their market choice decision and their efforts to access more income from the market. Linking farmers to high-value markets is crucial for their economic development [26].

As Bangladesh is now moving from subsistence to commercial agriculture, priority is given to the field of value-added agricultural products, extension services, information, fair prices for farmers, and access to high-value markets [27]. Nevertheless, the success of commercialization depends on the secure connection to better prices and access to premium markets. Market infrastructure and marketing facilities are not well-developed in Bangladesh. In addition, there are weaknesses in the proper coordination between research, extension services, and the marketing of agricultural produce [28]. There are gaps in the coordination of the system, regarding, for example, the invention and development of new varieties, the timely transfer of technology to farmers by extension workers, and the provision of assistance to market linkage facilities. Even the trading system and nature of the market vary from market to market. This sometimes creates difficulties for the supply of reliable market information required to access the market. However, a very limited numbers of studies have been conducted in Bangladesh to identify the factors responsible for the market participation decisions of farmers. Osmani and Hossain [29] focused on the determinants of smallholder farm commercialization and recommended the development of market infrastructure and institutional market information services to enhance commercialization. Most of the previous studies focused on the determinants of 
smallholder farmers commercialization. Therefore, there is a gap in the factors associated with market choices made by commercialized farmers and the effect that this participation has on prices.

A few studies, for example, [30-32] attempted to measure the impact of market participation on outcomes such as producer's price, profitability and income. Negi et al. [32] used an ordinary least square (OLS) estimation; however, OLS suffers from selection bias. Retsef et al. [31] used propensity score matching (PSM) but failed to use multiple robustness checks to show the consistency of their findings. Moreover, Mulubrhan et al. [30] applied difference in differences (DID), but the assumed common trend of their study remains questionable. As a result, there remains a need to address the gaps in previous studies by employing a causal inference method with proper robustness checks.

A linear probability model (LPM) was used to identify the factors associated with large wholesale market participation decisions, and propensity score matching (PSM) was applied to estimate the impact of the decision to participate in the large wholesale market on producer price. In addition, inverse probability weighted regression adjustment (IPWRA) and Mahalanobis distance matching (MDM) were used as robustness checks to complement our main findings. To the best of our knowledge, no studies have been conducted to determine the influencing factors on the decisions of brinjal (aubergine) farmers to participate in the large wholesale market, and to measure the effect of this on producer price in the country. Therefore, this study was an effort to fill the research gap and aid policymakers by understanding the factors behind this subject. Thus, the main objective of this study was to identify the influencing factors on farmers' large wholesale market participation decisions for selling their produce and, subsequently, the impact on producer price for brinjal (aubergine) farmers.

\section{Materials and Methods}

\subsection{Study Sites}

The study was conducted in two districts, namely Jashore and Narsingdi. Jashore district is located in southwestern region, whereas Narsingdi district is located at central region of Bangladesh (Figure 1). These two districts are geographically separate from each other in Bangladesh. However, the economy of Jashore and Narsingdi are predominantly dependent on agriculture. Nearly, $63.38 \%$ and $51.22 \%$ of the total households in Jashore and Narsingdi districts are agriculture farm holdings [24]. Due to fertile land and favorable climate conditions, these two districts are very suitable for brinjal (aubergine) production. About $30-60 \%$ of the locally produced vegetables in Jashore are transported to the capital city, Dhaka [33].

One sub district from each district, "Sadar" sub-district from Jashore and "Belabo" sub-district from Narsingdi, were selected for this study (Figure 1).

In the study areas, there are two types of wholesale markets: one is a large wholesale market situated near the main center of the sub-district and the others are small wholesale markets (locally known as haat) located in the village areas. Generally, farmers participate in either the large wholesale market or small wholesale market in these study areas.

Small wholesale market: In the small wholesale market, trade is operated by the direct sales by the producers to small wholesale market traders or the partners of large wholesale traders. Small wholesale markets are usually arranged on a periodic basis or on specific weekdays. These markets are commonly organized at a central place in villages or beside a main road connected with a district highway. In small wholesale market, local retailers, local commission agents, and local wholesalers are the buyers of farmers' brinjal (aubergine), but local commission agents work as commission agents between the farmers and traders (local retailers, local wholesalers). Local wholesalers (locally known as bepari) are the most important actors who supply different types of vegetables, mostly to capital city of Dhaka and other parts of the country. These local wholesalers are mostly the partners or appointed staff of the large wholesalers who normally buy brinjal (aubergine) from the large wholesale market. 


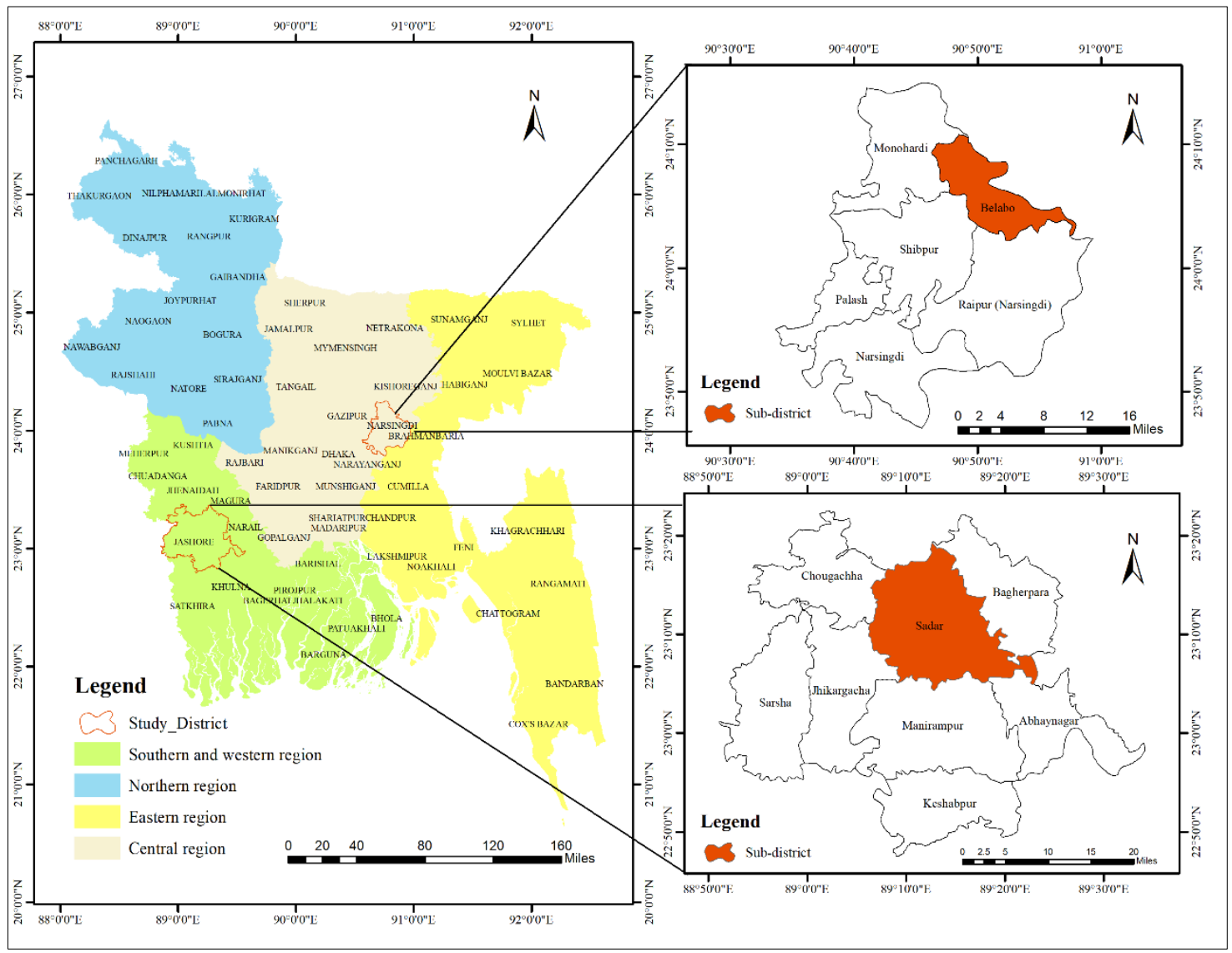

Figure 1. Study area, Bangladesh. Source: Authors.

Large wholesale market: A market in which producers and buyers are in large number; the size of market is also large since a large volume of produced is traded, there is a large number of producers and buyers, the market operates every day, and the market is located in the center of a sub-district. Local wholesalers (who purchase large in bulk sizes) are the direct buyers from the farmers in large wholesale markets. They supply vegetables mostly to the capital city of Dhaka and other regions in the country.

\subsection{Conceptual Framework of Market Participation}

The conceptual framework (Figure 2) implies the interrelationships of explanatory variables used in this study and how they are interdependent. The socio-economic factors were age, gender, marital status, family size, years of schooling, farming experience, brinjal cropped area, cultivated varieties, and yield. The institutional factors were road quality from farm to market, access to extension services and group marketing. The marketing factors were distance from farm to large wholesale market and transportation cost.

The physical factor was road quality from farm to market, and the informal factor was trust-based credit from traders. Due to the above factors, farmers' participation decisions in large and small wholesale markets and producer's prices vary. 


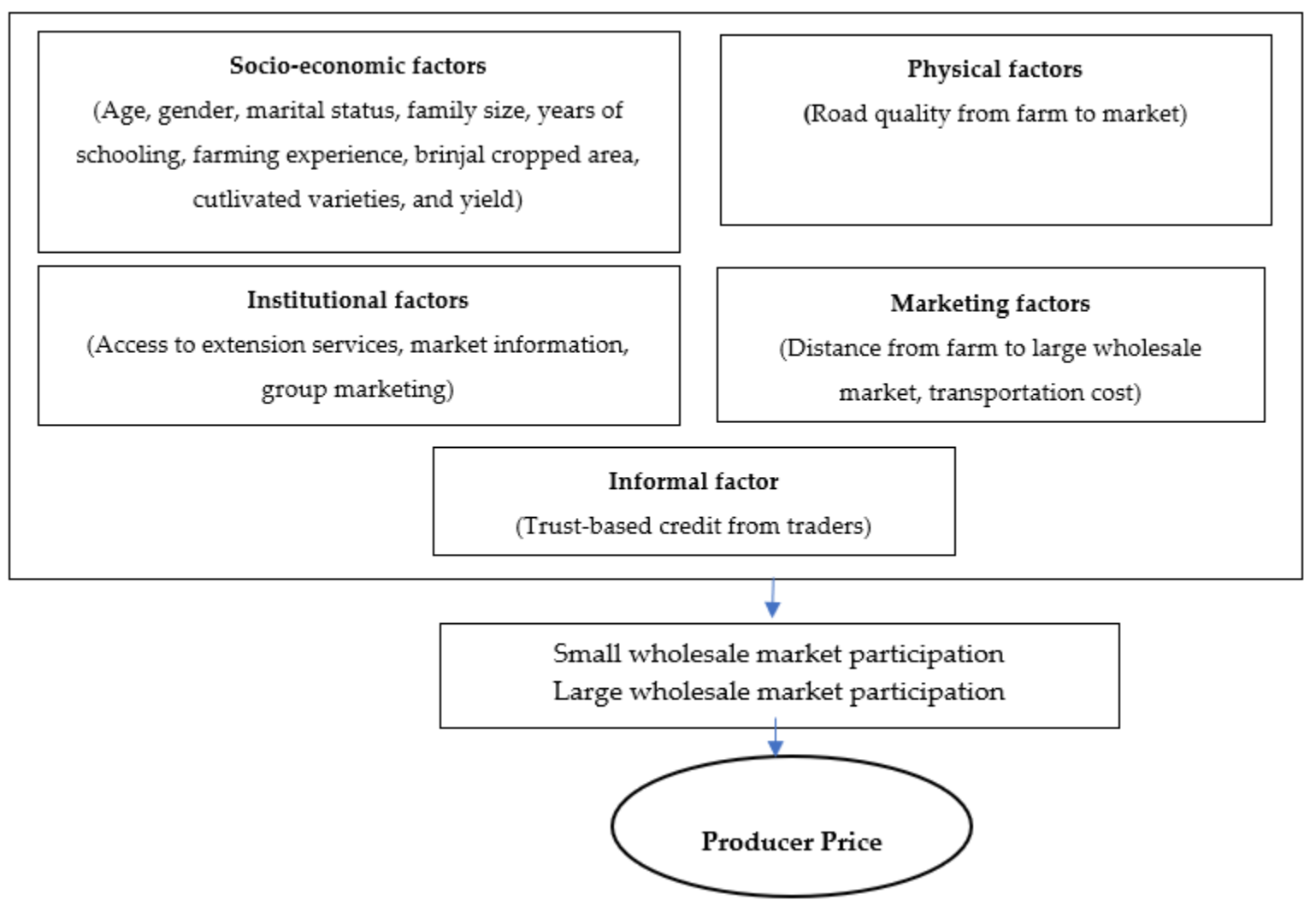

Figure 2. Conceptual framework of market participation Source: Authors' own elaboration.

\subsection{Sampling Procedure}

The target population was all farmers engaged in brinjal (aubergine) cultivation who sold their produce to markets in two districts, Jashore and Narsingdi. As per information from subdistrict agricultural offices, there are 1541 farmers who cultivate brinjal and mostly depend on market participation for selling their brinjal (aubergine). Among them, 250 brinjal (aubergine) farmers were randomly selected. However, a total 209 farmers responded to the survey during the study period. After completing the survey, we found that 193 respondents completed the questionnaire; the remaining farmers were not included in the sample due to incomplete the questionnaire. Among 193 respondents, 108 farmers participated in the small wholesale market and 85 farmers participated in the large wholesale market.

\subsection{Data Collection}

Data were collected through face-to-face interviews with the semi-structured questionnaire. The questionnaire included both open- and closed-ended questions. The data included socioeconomic characteristics, household characteristics, yield, sales price (Table 1). Before conducting final survey, the questionnaire was approved by the research ethics committee, Graduate School of International Development and Cooperation (IDEC), Hiroshima University, Japan, with compliance to ethical aspects such as basic human rights, the protection of personal information and security of data. Questionnaires were pretested on farmers before conducting the final survey. Data were collected in the period from 15 August 2020 to 30 September 2020. 
Table 1. List of variables with descriptions and expected signs.

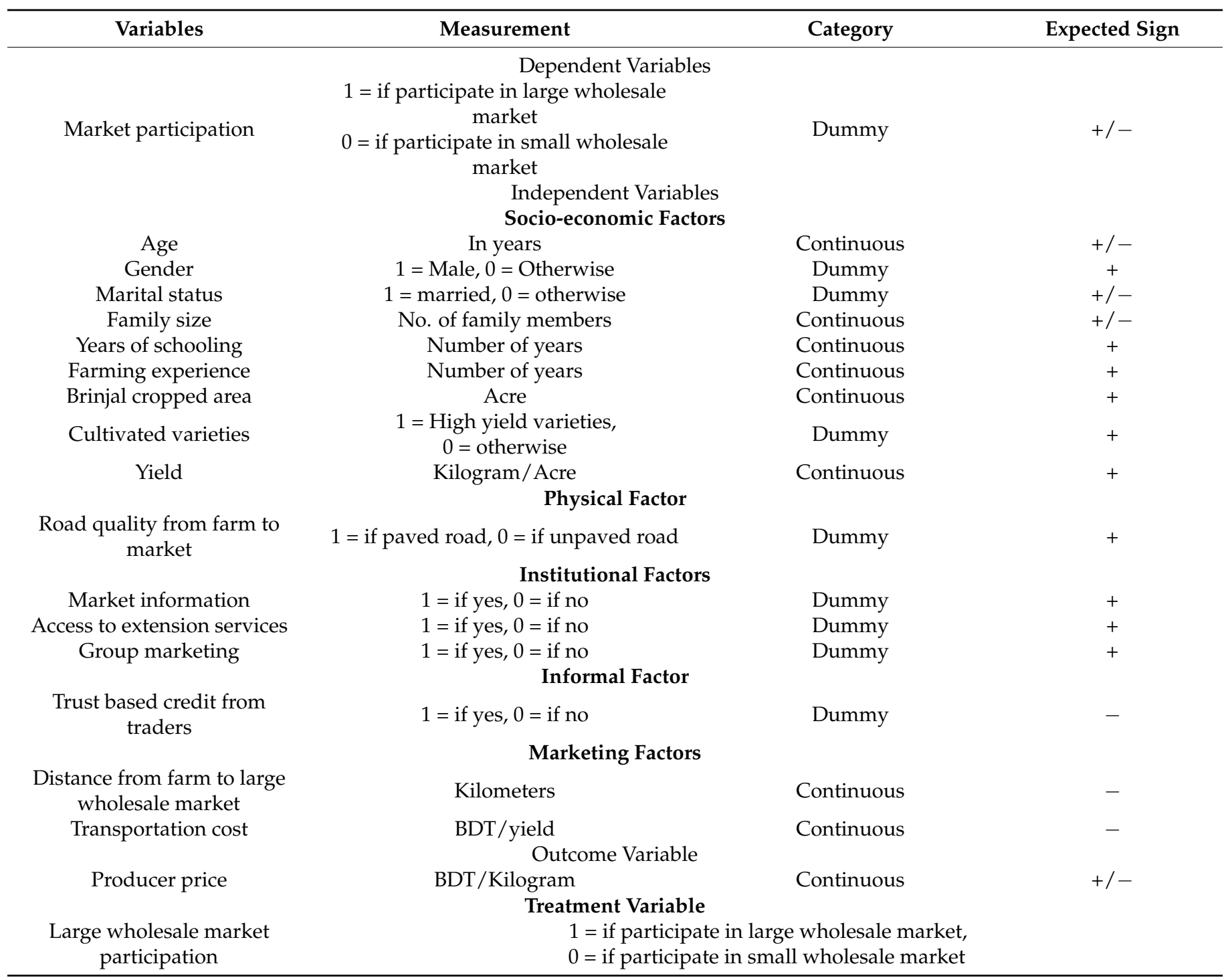

Source: Authors' own elaborations.

\subsection{Variable Selection}

This study selects various relevant explanatory variables that represent the conceptual framework of farmers market participation decisions (Figure 2). The justification for choosing each explanatory variable is discussed later in the justification part. Table 1 reveals and defines all the explanatory variables used in the study. Specifically, age, gender, marital status, family size, years of schooling, farming experience, and distance from farm to large wholesale market was used as farmers pretreatment characteristics to evaluate the effect of large wholesale market participation on outcome variable. Gender, education, and distance are considered as time invariant; age and farming experience were also treated as time invariant due to their proportional change of nature; and time variation of marital status, family size was considered negligible. These pre-treatment variables were selected according to the previous study of $[10,34,35]$

\subsection{Outcome Variable}

This study's outcome variable is producer's price, the price received from the market which the farmers participated in (either in large or small wholesale market). Table 1 also describes the outcome variable used in this study. 


\subsection{Data Analytical Method}

Two types of statistical methods were used to analyze the collected data. Independent variables were categorized based on socio-economic factors, physical factors, institutional factors, marketing factors and informal factors. Based on the independent variables, the linear probability model equation was derived to identify the probable factors associated with large wholesale market participation by farmers. The following linear probability model shown in Equation (1):

$$
Y(0,1)=\beta_{0}+\beta_{1} X_{1}+\beta_{2} X_{2}+\ldots \ldots \ldots \ldots+\beta_{n} X_{n}+\varepsilon_{i}
$$

where $\mathrm{Y}(0,1)$ is a dependent variable, market participation is denoted by $(0,1)$, large wholesale market participation is denoted by 1 , and small wholesale market participation denoted by 0 . The variable $\beta_{0}$ is a constant, $\beta_{1}, \ldots, \beta_{\mathrm{n}}$ are parameters to be estimated, $X_{1}, \ldots, X_{n}$ are the vectors of the explanatory variables, and $\varepsilon_{\mathrm{i}}$ is the error term.

In a non-experimental study, treatment is non-random [36]. If the treatment is not randomly assigned, a mere comparison of the treated and the control group will induce bias estimation. In our study, large wholesale market participation is not randomly assigned to farmers' levels of participation, so if the farmers who participate in large wholesale markets are compared to those who do not participate in these markets, this will cause selection bias. For instance, in this study, many farmers did not participate in large wholesale markets due their dependence on the observable and unobservable characteristics. In such cases, the potential observed, and unobserved confounding variables may affect both the response and treatment variables, which causes a selectivity bias [34]. The best identification strategy is randomized control trial (RCT) to address the selection bias, but RCT is often expensive and infeasible to implement. Quasi-experimental designs are the best alternative under proper assumptions. To address the selection bias, this study applies quasi experimental identification propensity score matching (PSM) because it imitates randomized experiments. PSM define randomization [37] while assigning the treatment by matching the treated observations with the untreated observations. Many studies even apply the matching method as a useful tool to relieve potential selection bias issues $[36,38]$. Thus, propensity score matching (PSM) was used to estimate the effect of treatment variables (large wholesale market participation) on producer price. The difference of outcome variable between treatment and control group of producer price by applying average treatment effect on treated (ATET) can be expressed as:

$$
\operatorname{ATET}(\mathrm{x})=\mathrm{E}\left[\left(\mathrm{Y}_{1} \mid \mathrm{p}=1, \mathrm{p}(\mathrm{x})\right)-\left(\mathrm{Y}_{0} \mid \mathrm{p}=1, \mathrm{p}(\mathrm{x})\right)\right]
$$

where $\mathrm{p}=$ participation in large wholesale market $(\mathrm{p}=1$ if participated in large wholesale market), $X$ is a set of pretreatment characteristics, $Y_{1}$ is the potential outcome when treated (producer price for large wholesale market participants as treated group), $\mathrm{Y}_{0}$ is the potential outcome when the unit is untreated (producer price for small wholesale market participants as control group). Despite the benefits of PSM, due to misspecification in PSM, the ATET estimation from PSM may be biased. According to [34], utilizing the inverse probability weighted regression adjustment (IPWRA) method solves such a predicament. IPWRA has a double robust characteristic, which provides consistent outcomes. It avoids misspecification bias by giving the outcome and treatment model for misspecification. Thus, IPWRA was used to check the robustness of PSM estimation results in this study. To complement the findings, this study further used Mahalanobis distance matching (MDM). Propensity score matching (PSM) and Mahalanobis distance matching (MDM) differ in the estimation of treatment effect. PSM reduces the space of covariates to a single dimension as it depends on pairing treated and control units that have similar propensity scores. On the other hand, MDM depends on pairing treated and control units that are close in terms of pretreatment covariates. 


\subsection{Justification for Inclusion of Independent Variables \\ 2.8.1. Age}

Age of brinjal (aubergine) farmers was measured in years. Age influenced participation in market choice through diverse ways such as experience, risk preference and access to resources $[39,40]$. Younger farmers are expected to take more risks and be more energetic and innovative in making decision on market choice. On the contrary, older farmers are expected to have more experience and access to resources [41]. Therefore, our hypotheses were that the expected sign might be positive or negative in this study.

\subsubsection{Gender}

Gender influences market choice decisions made by male- and female-headed households [39]. The gender of the farmer was set as dummy variable, where male farmers took the value of 1 ; otherwise, the value was zero. It was assumed as a negative sign that male farmers have better access to input and output markets with more communicative knowledge, which might provide wider options for market decisions compared to female farmers.

\subsubsection{Marital Status}

Farmers who are young and unmarried might have a positive influence on participation in the large wholesale market, or those who are married might have more experience that can influence participation in the large wholesale market. Maspaitella et al. [42] argued that younger farmers were more innovative and risk takers. Thus, it was expected to be positive/negative sign in this study.

\subsubsection{Family Size}

Family size was used as a continuous variable indicating the number of family members in a household. Jaleta et al. [43] argued that a larger household size leads to market participation decisions that can help farming activity. In contrast, [21] found that a larger household negatively influenced participation in the market due to dependence on consumption and more family labor required for farming activity. Thus, it was expected to be a positive/negative sign in this study.

\subsubsection{Years of Schooling}

Years of schooling of farmers was taken as continuous variable meaning the number of years spent in formal educational institution. Farmers with more schooling years may have better skills, knowledge and utilize market information to improve their marketing practices. The higher level of schooling years was found to positively affect farmers' participation in their ability to make quick decisions compared to those who had a lower level of schooling years $[5,41,44]$. Thus, it was considered that years of schooling might have a positive correlation with market choice decision.

\subsubsection{Farming Experience}

Farming experiences improve long-term relationships with traders and have more bargaining power in market output for selling brinjal, connecting with traders, and acquiring more market information. According to [45], the farming experience improves farmer's negotiation skills. Thus, it was expected as a positive sign in this study.

\subsubsection{Brinjal Cropped Area}

Farmers who cultivated a large area of brinjal might have an increased probability of participating in the large wholesale market. It was also assumed that a large farm size might have other multiple agriculture produces, which indicates more experience and market knowledge that helps to make the decision to participate in the market. The increase in land under vegetables cultivation and a large farm size positively influenced the choice 
of market and channels [46,47]. Thus, it was measured as a continuous variable per acre and expected to be a positive sign.

\subsubsection{Cultivated Varieties}

Cultivated varieties were measured as dummy variables that took the value of 1 if the farmer adopted high yielding varieties or Bt brinjal and zero otherwise. In each district, farmers typically cultivate hybrid and local varieties most suited to the local conditions and markets. Some preferred varieties in the study areas are hybrid (such as BARI-2, and BARI-4 developed by Bangladesh Agricultural Research Institute (BARI)), Bt (Bacillus thuringiensis) brinjal and locally improved varieties (local varieties are developed seed/seedlings grown by storing seeds from the harvest and maintain them at a household temperature over the years). The color, size, and taste of fruits of brinjal (aubergine) depend on the cultivated varieties. Kangile et al. [8] noted that the decision of farmers to select a particular market or channel is complex and influenced by the type of product. Therefore, it was expected as positive sign in this study that farmers' decisions might have a positive influence on large wholesale market participation decision.

\subsubsection{Distance from Farm to Large Wholesale Market}

The distance from farm to large wholesale market is a continuous variable measured in kilometers, and it was expected to be a negative sign. The closer the distance from farm location to market, the lesser transportation cost, and the nearer the market, the more preferable market participation. Several studies found a negative influence of distance on smallholder farmers participation in the market [21,47-50]. Farmers who had a farm located far away from large wholesale markets might be less likely to sell produce in large wholesale markets and would participate in a nearer market.

\subsubsection{Road Quality from Farm to Market}

The road quality from farm to market was expected to be a positive influence on market participation and assumed that farmers' decisions depended on the quality of the road directly between the farm location to market. This was categorized as a dummy variable for paved road and unpaved road connections from farm location to market. Farmers who had access to paved road connections from farm location to market may have better access to transportation facilities, better market information, and would save time accessing the market, positively influencing their market participation decisions. Two studies found that farmers near the main road had better access to market information and transportation [51,52].

\subsubsection{Access to Extension Services}

Farmers who had access to extension services regarding market linkages with large wholesalers, free weight facilities for produce at large wholesale markets, training and advisory services regarding soil treatment, seed and seedling preparation, application of optimal input use such as fertilizer and pesticides preparation, sorting, and packaging might positively influence market participation decisions. Mcnamara and Tata [53] found that access to extension services brought knowledge, market information and technical skills for smallholder's vegetable farmers. Therefore, it was assigned as positive sign for this dummy variable.

\subsubsection{Market Information}

Farmers who had prior contracts with Farmers Information and Advice Center (FIAC) and fellow farmers via telephone and social network contact, the relationships between price information, information about the buyers and operational information about the market might have a positive influence on making the appropriate decisions for market participation. Market information helped to improve farmer knowledge of the market and 
form an appropriate plan to sell rice in the market [5]. Thus, it was measured as a dummy variable and expected as positive sign in this study.

\subsubsection{Group Marketing}

Farmers who were members of Common Interest Group (CIG), hired transport in a group, or shared transport costs were considered as a performing marketing group in the study areas. Shiferaw et al. [54] found that farmers' group and collective action enhanced their ability to negotiate better prices and improved their market power.

\subsubsection{Trust-Based Credit from Traders}

Farmers who had trust-based credit from their traders before harvesting, at the next selling, or at the time of cultivation were given the promise that they could sell their produces to traders. This is not like formal credit services; it was totally dependent on trust-based credit services between producers and traders. However, regarding formal credit services, some studies found that access to credit was positively related with output market participation and more value addition [41]. On the contrary, it was assigned as dummy variable and expected as a negative sign that may have constrained farmers to make decisions on market choice freely in order to participate in the market.

\subsubsection{Yield}

Yield was considered as a proxy measure of the total production of brinjal (aubergine) in cultivated land size. It was measured in kilogram per acre as a continuous variable. An increase in production was found to increase farmer's market participation [5]. Therefore, the total yield of brinjal (aubergine) was hypothesized to have a positive influence on market participation decision.

\subsubsection{Transportation Cost}

Transportation cost was considered as the amount spent per season for transporting brinjal (aubergine) from farm to market where he/she participated in the market. The higher the transportation cost, the lesser the possibility of participate in the large wholesale market. Thus, it was considered as a continuous variable and expected as negative sign in this study.

\section{Results and Discussion}

\subsection{Demographic, Socioeconomic, Farm and Market Related Characteristics of Farmers}

Table 2 describes the descriptive statistics of the farmer's demographic, socio-economic, farm- and market-related characteristics between the participants of the large and small wholesale markets. The sample of 193 farmers identified that 85 farmers participated in the large wholesale market and 108 farmers participated in the small wholesale market. Among the sample, $44.04 \%$ farmers participated in the large wholesale market and $55.96 \%$ participated in the small wholesale market. The variables of age, marital status, family size, farming experience and transportation cost are not significantly different between the large wholesale market and small wholesale market participants. On the other hand, the variables of gender, years of schooling, brinjal cropped area, distance from farm to large wholesale market, yield and producer's price were significantly different between the large wholesale market and small wholesale market participants. 
Table 2. Descriptive statistics of selected variables of brinjal (aubergine) farmers.

\begin{tabular}{|c|c|c|c|c|c|c|c|c|}
\hline \multirow{2}{*}{ Variables } & \multicolumn{3}{|c|}{$\begin{array}{l}\text { Large Wholesale Market } \\
\qquad(\mathrm{N}=85)\end{array}$} & \multicolumn{3}{|c|}{ Small Wholesale Market $(\mathrm{N}=108)$} & \multirow{2}{*}{$\begin{array}{c}\text { Mean } \\
\text { Difference }\end{array}$} & \multirow[t]{2}{*}{$p$-Value } \\
\hline & Mean & Min. & Max. & Mean & Min. & Max. & & \\
\hline Age & $\begin{array}{c}43.41 \\
(10.99)\end{array}$ & 22 & 70 & $\begin{array}{c}45.45 \\
(10.00)\end{array}$ & 24 & 65 & 2.04 & 0.179 \\
\hline Gender & $\begin{array}{c}0.94 \\
(0.23)\end{array}$ & 0 & 1 & $\begin{array}{c}0.85 \\
(0.36)\end{array}$ & 0 & 1 & $-0.09 * *$ & 0.048 \\
\hline Marital status & $\begin{array}{c}0.87 \\
(0.33)\end{array}$ & 0 & 1 & $\begin{array}{c}0.92 \\
(0.26)\end{array}$ & 0 & 1 & 0.05 & 0.202 \\
\hline Family size & $\begin{array}{c}5.02 \\
(1.18)\end{array}$ & 3 & 8 & $\begin{array}{c}5.12 \\
(1.29)\end{array}$ & 3 & 9 & 0.09 & 0.593 \\
\hline $\begin{array}{l}\text { Years of schooling } \\
\text { (years) }\end{array}$ & $\begin{array}{c}7.24 \\
(3.23)\end{array}$ & 0 & 17 & $\begin{array}{c}5.02 \\
(3.29)\end{array}$ & 0 & 12 & $-2.21^{* * *}$ & 0.000 \\
\hline $\begin{array}{l}\text { Farming experience } \\
\text { (years) }\end{array}$ & $\begin{array}{c}23.72 \\
(10.05)\end{array}$ & 3 & 43 & $\begin{array}{c}24.12 \\
(10.78)\end{array}$ & 5 & 52 & 0.39 & 0.797 \\
\hline $\begin{array}{l}\text { Brinjal (aubergine) } \\
\text { cropped area (acre) }\end{array}$ & $\begin{array}{c}0.45 \\
(0.28)\end{array}$ & 0.08 & 2.00 & $\begin{array}{c}0.27 \\
(0.13)\end{array}$ & 0.05 & 1 & $-0.18^{* * *}$ & 0.000 \\
\hline $\begin{array}{l}\text { Distance from farm } \\
\text { to large wholesale } \\
\text { market (kilometers) }\end{array}$ & $\begin{array}{c}3.55 \\
(1.26)\end{array}$ & 1.50 & 8.50 & $\begin{array}{c}4.68 \\
(1.18)\end{array}$ & 3 & 8 & $1.14^{* * *}$ & 0.000 \\
\hline $\begin{array}{c}\text { Yield } \\
\text { (kilogram)/acre }\end{array}$ & $\begin{array}{l}14,010 \\
(1143)\end{array}$ & 10,900 & 16,500 & $\begin{array}{c}12,932 \\
(905)\end{array}$ & 11,200 & 15,500 & $-1077^{* * *}$ & 0.000 \\
\hline $\begin{array}{l}\text { Producer Price } \\
\text { (BDT/kilogram) }\end{array}$ & $\begin{array}{l}24.68 \\
(2.58)\end{array}$ & 19 & 30 & $\begin{array}{l}20.67 \\
(2.51)\end{array}$ & 15 & 26 & $-4.01^{* * *}$ & 0.000 \\
\hline $\begin{array}{l}\text { Transportation cost } \\
\text { (BDT/yield) }\end{array}$ & $\begin{array}{c}9251 \\
(2805)\end{array}$ & 5000 & 18,000 & $\begin{array}{c}8713 \\
(2684)\end{array}$ & 4500 & 18,500 & -537 & 0.177 \\
\hline
\end{tabular}

Note: Numbers in the parenthesis are standard deviation; $\min =$ minimum; $\max =$ maximum; significance at *** 1 percent, ${ }^{* *} 5$ percent (USD 1 = BDT 85) Source: Authors' own calculation.

In Table 3, the results show the frequency of selected dummy variables of brinjal (aubergine) farmers for road quality from farm to market, access to extension services, market information, group marketing, trust-based credit from traders, and cultivated varieties between the two market participants.

Table 3. Frequency of selected dummy variables of brinjal (aubergine) farmers.

\begin{tabular}{|c|c|c|c|c|c|c|}
\hline \multirow[t]{2}{*}{ Variable } & \multirow[t]{2}{*}{ Measurement } & \multicolumn{2}{|c|}{$\begin{array}{c}\text { Large Wholesale } \\
\text { Market } \\
(\mathrm{N}=85)\end{array}$} & \multicolumn{2}{|c|}{$\begin{array}{c}\text { Small Wholesale } \\
\text { Market } \\
(\mathrm{N}=108)\end{array}$} & \multirow[t]{2}{*}{$\begin{array}{c}\text { Overall } \\
\text { Frequency }\end{array}$} \\
\hline & & Frequency & $\%$ & Frequency & $\%$ & \\
\hline \multirow{2}{*}{ Road quality from farm to market } & Paved road & 63 & 74 & 14 & 13 & 77 \\
\hline & Unpaved road & 22 & 26 & 94 & 87 & 116 \\
\hline \multirow{2}{*}{ Access to extension services } & Yes & 60 & 70 & 32 & 29 & 92 \\
\hline & No & 25 & 30 & 76 & 71 & 101 \\
\hline \multirow{2}{*}{ Market information } & Yes & 60 & 70 & 30 & 28 & 90 \\
\hline & No & 25 & 30 & 78 & 72 & 103 \\
\hline \multirow{2}{*}{ Group marketing } & Yes & 61 & 72 & 24 & 22 & 85 \\
\hline & No & 24 & 28 & 84 & 78 & 108 \\
\hline \multirow{2}{*}{ Trust-based credit from traders } & Yes & 4 & 5 & 38 & 35 & 42 \\
\hline & No & 81 & 95 & 70 & 65 & 151 \\
\hline \multirow{2}{*}{ Cultivated varieties } & HYV & 80 & 94 & 67 & 62 & 147 \\
\hline & Local varieties & 5 & 6 & 41 & 38 & 46 \\
\hline
\end{tabular}




\subsection{Factors Associated with Large Wholesale Market Participation Decision by The Farmers}

The results in Table 4 indicate the factors that influenced the probability of participating in the large wholesale market by the brinjal (aubergine) farmers in Jashore and Narsingdi districts.

Table 4. Linear Probability Model- Factors that were associated with large wholesale market participation decisions by farmers.

\begin{tabular}{cccc}
\hline Variables & Coefficient & Std. Err. & Significance \\
\hline Age & -0.00008 & 0.00352 & 0.816 \\
Gender & 0.07074 & 0.07216 & 0.328 \\
Marital status & 0.03420 & 0.08466 & 0.687 \\
Family size & -0.01012 & 0.17109 & 0.555 \\
Years of Schooling & $0.01487^{* *}$ & 0.00694 & 0.034 \\
Farming experience & $0.00059^{*}$ & 0.00344 & 0.864 \\
Brinjal (aubergine) & $0.18316^{*}$ & 0.10135 & 0.072 \\
cropped area & $0.07109^{*}$ & 0.05544 & 0.201 \\
Cultivated varieties & & & 0.000 \\
Distance from farm to & $-0.08387^{* * *}$ & 0.02149 & \\
large wholesale & & & 0.000 \\
market & $0.28003^{* * *}$ & 0.05182 & 0.074 \\
Road quality from & & & 0.005 \\
farm to market & $0.08381^{*}$ & 0.04670 & 0.000 \\
Access to extension & $0.13093^{* * *}$ & 0.04567 & 0.070 \\
services & $0.22487^{* * *}$ & 0.04675 & 0.000 \\
Market information & $-0.09814^{*}$ & 0.05384 & 0.068 \\
Group marketing & $0.00009^{* * *}$ & 0.00002 & 0.001 \\
Trust based credit & $0.00001^{*}$ & 0.00001 & \\
from traders & -1.08221 & 0.31112 & 0.7087 \\
Yield & & $* *$ percent* & 10 percent Source: Authors own calculations.
\end{tabular}

Years of schooling: Years of schooling of the household head was positively related to the probability of a household's decision to participate in the large wholesale market, and it was significant at a $5 \%$ level. The positive coefficient implies that the increased education level of household heads increased large wholesale market participation by $1.48 \%$. This means that education level is important in the choice of market as it enables more information to be acquired, as well as new ideas and technology that increase their surplus production, therefore increasing farmers' participation in the large wholesale market. For example, Ref. [55] identified that farmers who participated in conventional markets were typically less educated.

Brinjal cropped area: The brinjal cropped area had positive correlation on the participation of the large wholesale market and was significant at a 10\% level. This implied that the probability of participation from farmers in the large wholesale market increased by $18.31 \%$ if the one-acre brinjal (aubergine) cropped area increased. The farmers who had more land allocation for brinjal (aubergine) cultivation positively affected participation in large wholesale markets due to increased yield, and they might have multiple crop cultivations and a long-term relationship with the large wholesale market. This finding is corroborated by Xaba and Masuku [47], who found that having more land had a positive impact on the choice of large sales channels by vegetable farmers in Swaziland.

Distance from farm to large wholesale market: This variable had negative correlation with participation in the large wholesale market, and it was significant at a $1 \%$ level. It indicated that the probability of participation by the farmers in the large wholesale market decreased by $8.38 \%$ if the distance from the farm location to the large wholesale market 
increased by one kilometer. According to Kyaw et al. [5], the distance to the market was an indicator of travel time and transportation cost. Therefore, the larger the distance from farm to large wholesale market, the lower the participation of large wholesale market by the farmers.

Road quality from farm to market: Road quality from farm location to market was expected to have positive relationship with participation in the large wholesale market. It indicated that farmers with paved roads have a $28 \%$ higher probability of participating in the large wholesale market, compared to farmers with unpaved roads $(1 \%$ significance level). Slamet et al. [15] found that small-scale vegetable farmers located near paved roads were more likely to participate in the modern market, such as supermarkets, in Indonesia.

Access to extension services: Access to extension services increased the probability of participating in the large wholesale market by $8.38 \%$ at a $10 \%$ significance level. It implied that farmers who had access to extension services, such as training and advisory services regarding seed bed preparations, fertilizer and pesticides application, packaging method, and market linkages, facilities a positive influence on participation in large wholesale market with the buyers.

Market information: The coefficient of market information showed a positive correlation with participation in the large wholesale market, and it increased the probability of participating in the large wholesale market by $13.09 \%$ at a $1 \%$ significance level. Farmers used market price information and operational activities, such as market open days, by communicating with the Farmers Information and Advice Center (FIAC) and fellow farmers via telephone to find price information on the market, and thus the premium price. This emphasizes the importance of institutional services, social networking with fellow farmers and the usage of technology to obtain market information. Similarly, some studies show that the availability of market information positively influenced the choices of market and channel participation [5,51,56-58].

Group marketing: The positive coefficient of group marketing indicates that it increased the probability of participation in the large wholesale market by $22.48 \%$, provided that farmers practiced group marketing, and it was significant at $1 \%$ level. This means that farmers who were members of the Common Interest Group (CIG), hired transport and shared costs in a group positively influenced participation in the large wholesale market. Mukarumbwa et al. [59] found a positive relationship between members of the association and small groups of farmers and participation both in local and urban markets.

Trust-based credit from traders: Trust-based credit from traders had a negative impact, as expected, and it had a negative association with participation in the large wholesale market with a significance at the $10 \%$ level. It implied that the probability of farmers participation in the large wholesale market decreased by $9.81 \%$ if farmers had trust-based credit from traders. Negi et al. [32] identified that small farmers in India who availed inputs and credit from traders via informal channels compelled them to sell their produce as collateral. In the study areas, there was an informal agreement between the farmers' and traders' relations, more specifically with the local commission agent in the small wholesale market, which was fully based on mutual trust where traders invest money to farmers for temporary periods for farmers' cultivation activities (purchase inputs such as labor, land preparation, fertilizer, pesticides) before harvesting. This was one kind of liability and tied transaction that negatively influenced participation in the large wholesale market, and farmers were limited to selling produce at the small wholesale market. Such informal settings also influenced producers price realizations.

Yield: The positive coefficient implies that the probability of participating in the large wholesale market increased by $0.009 \%$, if one kilogram of brinjal (aubergine) per acre increased and was statistically significant at $1 \%$ level. This implied that farmers with a higher yield of brinjal (aubergine) monitored the daily operation of the market and the large wholesalers that were present in the large wholesale market, and this was positively associated with the participation on large wholesale market. 
Transportation cost: Transportation cost had a positive relationship with the large wholesale market participation and was statistically significant at $10 \%$. This seems counterintuitive and contradicts prior expectations. Meanwhile, from a field survey, transaction cost could be fixed or proportional depending on the road quality, distance to market, mode of transportation and the level of production. Transportation cost was fixed when the road quality was unpaved and mode of transportation was a manually operated engine or semi-auto engine, but this variation depending on the paved road connection, availability of transportation and level of production marketed. Therefore, the higher the volume of sales, the more costs were incurred. The positive coefficient implied that it increased the probability of participation in large wholesale markets by $0.001 \%$ if transportation cost increased by BDT 1. This result was consistent with the study of Harriet et al. [3] that transportation cost positively influenced market participation decisions due to the higher volume of sold produce in the market.

\subsection{Effect of Large Wholesale Market Participation on Producer's Price}

The causal effect of large wholesale market participation on producer price is estimated using the propensity score matching (PSM) procedure.

By applying propensity score matching, this study first estimated average treatment effect on treated (ATET). Table 5 reveals the results of the PSM that show the average treatment effect on treated (ATET) estimates and explains how the producer price changes because of participation in the large wholesale market.

Table 5. Propensity score matching estimates.

\begin{tabular}{cccccccc}
\hline & \multicolumn{3}{c}{ Caliper (0.05) } & \multicolumn{2}{c}{ Nearest Neighbor Matching } & & Kernel \\
\cline { 2 - 7 } Variables & $\begin{array}{c}\text { Producer } \\
\text { Price } \\
\text { (BDT/Kg) }\end{array}$ & S. E & T-Stat. & $\begin{array}{c}\text { Producer } \\
\text { Price } \\
\text { (BDT/Kg) }\end{array}$ & S. E & $\begin{array}{c}\text { T-Stat. } \\
\text { Price } \\
\text { (BDT/Kg) }\end{array}$ & $\begin{array}{c}\text { S. E } \\
\text { T-Stat. }\end{array}$ \\
\hline $\begin{array}{c}\text { Large wholesale market } \\
\text { participation }\end{array}$ & $\begin{array}{c}\text { ATET } \\
4.63\end{array}$ & 0.57 & $8.07 * *$ & $\begin{array}{c}\text { ATET } \\
5.36\end{array}$ & 0.74 & $6.98 * *$ \\
\hline
\end{tabular}

Note: Significance at *** 1 Source: Authors' own calculations.

The treatment effect based on the propensity score matching showed a positive effect (Table 5) of large wholesale market participation on producer price for per kilogram brinjal (aubergine) than participation in the small wholesale market. The average treatment effect on treated (ATET) was measured using radius caliper matching (0.05), nearest neighbor matching, and kernel matching (Table 5) using a psmatch2 command implemented on STATA 17. The PSM results of three algorithms - caliper (0.05), nearest neighbor matching, and kernel—showed a differentiated positive effect on producer price for per kilogram brinjal (aubergine) by BDT—4.63, 5.36, and 4.80, respectively - than the small wholesale market.

However, the impacts of large wholesale market participation on producer price in all three matching methods were statistically significant at the $1 \%$ level. The inverse probability weighted regression adjustment (IPWRA) results also confirm that farmers' participation in the large wholesale market increased the producer price by BDT 4.83, more than the small wholesale market at a $1 \%$ significance level (Table 6).

Table 6. Robustness check: inverse probability weighted regression adjustment (IPWRA).

\begin{tabular}{|c|c|c|c|c|c|c|}
\hline IPWRA & $\begin{array}{l}\text { Producer Price } \\
\text { (BDT/kg) } \\
\text { Coeff. }\end{array}$ & Std. Err. & $\mathbf{z}$ & $p$-Value & \multicolumn{2}{|c|}{$\begin{array}{l}\text { (95\% Conf. } \\
\text { Interval) }\end{array}$} \\
\hline $\begin{array}{l}\text { Large wholesale market } \\
\text { participation }\end{array}$ & 4.83 & 0.42 & 11.28 & $0.000^{* * *}$ & 3.98 & 5.66 \\
\hline
\end{tabular}


To complement the findings of our main results, the treatment effect based on Mahalanobis distance matching (MDM) also showed a positive effect (Table 7) of large wholesale market participation on producer price for per kilogram brinjal (BDT 3.79).

Table 7. Robustness check: Mahalanobis distance matching (MDM).

\begin{tabular}{cccc}
\hline MDM & $\begin{array}{c}\text { Producer Price } \\
\text { (BDT/Kg) } \\
\text { Coeff. }\end{array}$ & Std. Err. & T-Stat. \\
\hline $\begin{array}{c}\text { ATT } \\
\begin{array}{c}\text { Large wholesale } \\
\text { market participation }\end{array}\end{array}$ & 3.79 & 0.39 & $9.62^{* * *}$ \\
\hline Note: Significance at ${ }^{* * *}$ 1 percent. Source: Authors' own calculations.
\end{tabular}

There is an overlap and treatment off support regions (Figure 3c) in the range of the propensity score between the treatment and control groups before matching. The graph (Figure 3c) shows the propensity score for all untreated observations (108) for small wholesale market participants and treated observations (85) for large wholesale market participants. However, out of 85 treated observations, 12 farmers were off support regions and 73 farmers were from common support regions. Farmers from off support regions were not included in the matching process. According to Aku et al. [35], the exemption of a minimum number off support observations had a minimal effect on the reliability of the matching process. In fact, the common support provides an adequate sample for estimating the PSM effect parameter. However, after the matching (Balancing property in Table 8 ) between control and treated observations, the graph shows nearly homogeneous distributions (Figure 3b).

(a)

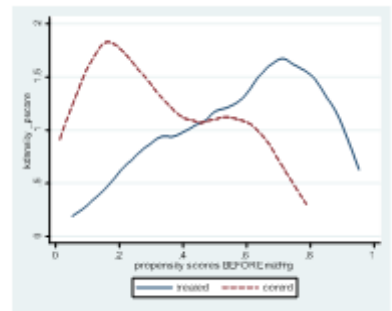

(b)

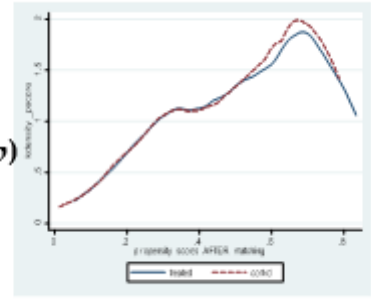

(c)

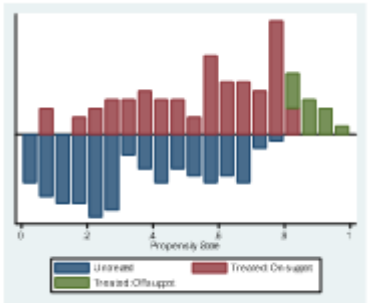

Figure 3. Propensity score graph: (a) before matching, (b) after matching and (c) overlap of the treated vs. untreated groups of market participants.

\section{Matching Quality Analysis}

The matching quality analysis was performed using a pstest command with the assigned covariates, which were used in the propensity score matching: age, gender, marital status, family size, years of schooling, farming experience, and distance from farm to large wholesale market between treatment group (large wholesale market participants) and control group (small wholesale market participants). Based on the balancing property (Table 8), we found that some covariates (gender, years of schooling and distance from farm to large wholesale market) in the unmatched sample were statistically significantly different between the treated and control groups. This implies that, before treatment, the covariates between the large and small wholesale market participants were imbalanced. According to Caliendo and Kopeining [60], the primary purpose of PSM is to balance all decided covariates. Therefore, this study also checks the balance of the chosen covariates across the treatment groups. Overall, the balance is considerably increased after matching. This indicates that the matching process is satisfied in balancing the pre-treatment characteristics.

Since the reliability of PSM and IPWRA results depends on the quality of our matching, we present the extent of overall covariate balancing, and the overlap of the common support and support regions. The overall covariate balancing test (Table 9) shows that 
the standardized mean difference for all covariates used in the PSM reduces from 34.2\% pre-matching to $17.9 \%$ post-matching.

Table 8. Balancing property for large and small wholesale market participants.

\begin{tabular}{|c|c|c|c|c|}
\hline \multirow{2}{*}{ Before Matching } & \multicolumn{2}{|c|}{ Mean } & \multirow{2}{*}{$\begin{array}{c}\text { Bias } \\
\text { Reduction (\%) }\end{array}$} & \multirow{2}{*}{$p$-Value } \\
\hline & Treated & Control & & \\
\hline Age & 43.412 & 45.454 & & 0.179 \\
\hline Gender & 0.94118 & 0.85185 & & $0.048^{* *}$ \\
\hline Family size & 5.0235 & 5.1204 & & 0.593 \\
\hline Marital status & 0.87059 & 0.92593 & & 0.202 \\
\hline Years of schooling & 7.2471 & 5.0278 & & $0.000^{* * *}$ \\
\hline Farming experience & 23.729 & 24.12 & & 0.797 \\
\hline $\begin{array}{l}\text { Distance from farm to } \\
\text { large wholesale market } \\
\text { After matching }\end{array}$ & 3.5471 & 4.6843 & & $0.000^{* * *}$ \\
\hline Age & 43.274 & 40.825 & -19.9 & 0.190 \\
\hline Gender & 0.94521 & 0.91553 & 66.8 & 0.485 \\
\hline Family size & 5.137 & 4.9473 & -95.9 & 0.364 \\
\hline Marital status & 0.86301 & 0.84397 & 65.6 & 0.747 \\
\hline Years of schooling & 6.6849 & 7.5118 & 62.7 & 0.109 \\
\hline Farming experience & 23.466 & 20.821 & -576.4 & 0.123 \\
\hline $\begin{array}{l}\text { Distance from farm to } \\
\text { large wholesale market }\end{array}$ & 3.7329 & 3.9767 & 78.6 & 0.165 \\
\hline
\end{tabular}

Table 9. Propensity scores matching quality test.

\begin{tabular}{ccc}
\hline Items & Before Matching & After Matching \\
\hline Pseudo R2 & 0.210 & 0.033 \\
$p$-value & 0.000 & 0.474 \\
Mean standardized bias & 34.2 & 17.9 \\
\hline
\end{tabular}

Source: Authors' own calculations.

Moreover, the joint significance of all covariates was never rejected before matching for small and large wholesale market participants $(p>x 2=0.000)$. However, the propensity score matching quality tests (Table 9 ) indicate that the joint significance of all covariates can be rejected after matching $(p>x 2=0.474)$. The low mean standardized bias and joint insignificance of the covariates are indicative of the successful balancing of the distribution of covariates between treated and untreated farmers.

\section{Conclusions and Policy Recommendation}

\subsection{Summary of Results and Conclusions}

The marketing of vegetables is important for ensuring better income, sustainable agriculture and promoting the betterment of farmers in local areas. This study found that the large wholesale market participation decision by brinjal (aubergine) farmers was associated with several factors such as socio-economic, physical, institutional, informal, and marketing factors. Large wholesale market participation by brinjal farmers was positively influenced by years of schooling, farm size, road quality from farm to market, access to extension services, market information, group marketing, yield, and transportation cost. On the other hand, large wholesale market participation was negatively influenced by distance from farm to large wholesale market and trust-based credit from traders.

This study also implies that farmers' participation and sales of their brinjal (aubergine) in the large wholesale market had a positive effect on producer price. This study addresses the gaps of previous studies because it considers commercial farmers. In addition to socioeconomic and institutional factors, it also considers physical and informal factors. Moreover, 
this is the first attempt in terms of estimating a causal impact of large wholesale market participation on producer's price, since previous studies merely identified an association.

\subsection{Policy Recommendation}

Through this study, we can provide some policy implications, as these variables have a significant effect on large wholesale market participation. All of the resulting factors require different policies, but some factors, especially socio-economic factors and market factors such as education level, farm size, yield, distance, and transportation cost cannot be easily changed by policy interventions. Therefore, the results of this study recommend that the Government adopt a comprehensive strategy for improving physical factors and institutional factors that ensure farmers' welfare. The Government should improve the road quality from farm locations to markets, ensure access to extension services, secure availability, provide accurate market information, and form a farmers marketing group, so that farmers' participation and selling activities in the remunerative markets can enhance and obtain better prices to ensure their welfare.

Moreover, trust-based credit from traders' customs should be agreed in the way that can positively affect farmers' freedom of choice to participate in market, or it could formally strengthen the long-term relationship between traders and farmers with no negative effects on farmers' price realization and market participation decisions. Moreover, the market should be organized to reduce the price differentials between the large and small wholesale markets.

\subsection{Limitations of the Study}

This study includes only the few factors that identify the probable relationship with market participation decisions. However, there are many other observable and unobservable factors such as cultural factors (religion; attendance of religious rituals; ethnic group; attitude towards risk and cultural beliefs of farmers about the capitalist market, etc.) and other socio-economic factors (ratio of hired labor and family labor employed in farming, physical and institutional factors; subsidies from the Government and other sources; market monitoring services, etc.) that might have a probable relationship with market participation decisions. To check the robustness of the relationship between market participation decisions and the impact of producer's price, this study did not employ any instrumental variable (IV) approach that could address the more unobserved bias and identify a robust causal relationship. Moreover, it did not cover the list of the samples in all villages in the study site; therefore, an insufficient sample size is one of the major limitations of this study. Considering cultural and other factors such as the instrumental variable approach, additional future studies are required to corroborate these findings and explore in more detail the factors influencing farmers' participation decisions in their choice of market and the robust impact on producer's price.

Author Contributions: Conceptualization, M.R.; Methodology, M.R. and K.L.M.; Software, M.R.; Formal analysis, investigation, resources, data curation, M.R.; Validation, M.R. and K.L.M.; Writingoriginal draft preparation, M.R.; Writing-Revision, review, editing, M.R. and K.L.M.; Visualization, M.R.; Supervision, K.L.M. All authors have read and agreed to the published version of the manuscript.

Funding: There is no funding for this research.

Institutional Review Board Statement: The study was conducted according to the guidelines and approved by the Ethics Committee of Graduate School for International Development and Cooperation (IDEC), Hiroshima University, Japan on 30 July 2020.

Informed Consent Statement: Informed consent was obtained from all farmers involved in this study.

Data Availability Statement: The survey data presented in this study are available on request from the corresponding author. 
Acknowledgments: The authors would like to thank Project for Human Resource Development Scholarship (JDS) organized by the Japan International Cooperation Agency (JICA) for financial support throughout the study period of M.R at Hiroshima University, Japan.

Conflicts of Interest: The authors declare no conflict of interest.

\section{References}

1. Abokyi, E.; Strijker, D.; Asiedu, K.F.; Michiel, N.D. The impact of output price support on smallholder farmers' income: Evidence from maize farmers in Ghana. Heliyon 2020, 6, e05013. [CrossRef]

2. Assouto, A.B.; Houensou, D.A.; Gervasio, S. Price risk and farmers' decisions: A case study from Benin. Sci. Afr. 2020,8 , e00311. [CrossRef]

3. Kyomugisha, H.; Sebatta, C.; Mugisha, J. Potato market access, marketing efficiency and on-farm value addition in Uganda. Sci. Afr. 2018, 1, e00013. [CrossRef]

4. Poole, N. Smallholder Agriculture and Market Participation; Food and Agriculture Organization of the United Nations (FAO): Rome, Italy, 2017; pp. 17-21.

5. Kyaw, N.N.; Ahn, S.; Lee, S.H. Analysis of the Factors Influencing Market Participation among Smallholder Rice Farmers in Magway Region, Central Dry Zone of Myanmar. Sustainability 2018, 10, 4441. [CrossRef]

6. United Nations. Transforming our World: The 2030 Agenda for Sustainable Development. Available online: https://bangladesh. un.org/en/sdgs/2 (accessed on 25 December 2021).

7. Jebesa, S. Determinants of Smallholder Farmers Market Participation and Outlet Choice Decision of Agricultural Output in Ethiopia: A Review. Am. J. Agric. For. 2019, 7, 139. [CrossRef]

8. Kangile, R.J.; Mgeni, C.P.; Mpenda, Z.T.; Sieber, S. The Determinants of Farmers' Choice of Markets for Staple Food Commodities in Dodoma and Morogoro, Tanzania. Agriculture 2020, 10, 142. [CrossRef]

9. Ngenoh, E.; Kurgat, B.; Bett, H.K.; Kebede, S.; Bokelmann, W. Determinants of the competitiveness of smallholder African indigenous vegetable farmers in high-value agro-food chains in Kenya: A multivariate probit regression analysis. Agric. Food Econ. 2019, 7, 2. [CrossRef]

10. Abdullah; Fazli, R.; Riaz, A.; Sajjad, A.; Abbas, A.C.; Waqar, A.; Aasir, I.; Izhar, U.D. Determinants of commercialization and its impact on the welfare of smallholder rice farmers by using Heckman's two-stage approach. J. Saudi Soc. Agric. Sci. 2019, 18, 224-233. [CrossRef]

11. Onoja, A.; Usoroh, B.; Adieme, D.T.; Deedam, N.J. Determinants of Market Participation in Nigerian Small- Scale Fishery Sector: Evidence from Niger Delta Region. Cons. J. Sustain. Dev. 2012, 9, 69-84.

12. Donkor, E.A.; Garnevska, E.; Siddique, M.I.; Donkor, E. Determinants of Rice Farmer Participation in the Direct Marketing Channel in Ghana. Sustainability 2021, 13, 5047. [CrossRef]

13. Hlatshwayo, S.I.; Ngidi, M.; Ojo, T.; Modi, A.T.; Mabhaudhi, T.; Slotow, R. A Typology of the Level of Market Participation among Smallholder Farmers in South Africa: Limpopo and Mpumalanga Provinces. Sustainability 2021, 13, 7699. [CrossRef]

14. Yaméogo, T.B.; Bossa, A.Y.; Torou, B.M.; Fusillier, J.-L.; Da, D.E.C.; Yira, Y.; Serpantié, G.; Somé, F.; Dama-Balima, M.M. SocioEconomic Factors Influencing Small-Scale Farmers' Market Participation: Case of Rice Producers in Dano. Sustainability 2018, 10, 4354. [CrossRef]

15. Slamet, A.S.; Nakayasu, A.; Ichikawa, M. Small-Scale Vegetable Farmers' Participation in Modern Retail Market Channels in Indonesia: The Determinants of and Effects on Their Income. Agriculture 2017, 7, 11. [CrossRef]

16. Ojulu, A. Reviews of Smallholder Farmers Market Participations Decisions and It Intensity in Ethiopia. Am. J. Manag. Sci. Eng. 2020, 5, 51. [CrossRef]

17. Egbetokun, O.A.; Omonona, B.T. Determinants of Farmers Participation in Food Market in Ogun State, Nigeria. Glob. J. Sci. Front. Res. 2012, 12, 24-30.

18. Hagos, A.; Dibaba, R.; Bekele, A.; Alemu, D. Determinants of Market Participation among Smallholder Mango Producers in Assosa Zone of Benishangul Gumuz Region in Ethiopia. Int. J. Fruit Sci. 2020, 20, 323-349. [CrossRef]

19. Bultossa, T.W.; Adeba, G. Determinants of Market Participation and Financial Profitability of Smallholder Dairy Farming: The Case of Bako Tibe, West Showa, Ethiopia. Trends Agric. Econ. 2016, 9, 29-44. [CrossRef]

20. Fredriksson, L.; Bailey, A.; Davidova, S.; Gorton, M.; Traikova, D. The commercialisation of subsistence farms: Evidence from the new member states of the EU. Land Use Policy 2017, 60, 37-47. [CrossRef]

21. Siziba, S.; Kefasi, N.; Diagne, A.; Fatunbi, O.; Adekunle, A.A. Determinants of cereal market participation by sub-Saharan Africa smallholder farmers. J. Agric. Environ. Sci. 2011, 2, 180-193.

22. Rahman, M.; Zhou, D.; Barua, S.; Farid, S.; Tahira, K. Challenges of value chain actors for vegetable production and marketing in North-East Bangladesh. GeoJournal 2021, 86, 1957-1967. [CrossRef]

23. Shelton, A.M.; Sarwer, S.H.; Hossain, M.J.; Brookes, G.; Paranjape, V. Impact of Bt Brinjal Cultivation in the Market Value Chain in Five Districts of Bangladesh. Front. Bioeng. Biotechnol. 2020, 8, 498. [CrossRef]

24. BBS. Yearbook of Agricultural Statistics. Bangladesh Bureau of Statistics (BBS), 2019. Available online: www.bbs.gov.bd (accessed on 20 July 2021). 
25. Ahmad, D.M.M. Supply chain of fruits and vegetables and correlated impact of managing the quality. In Proceedings of the Fourth International Conference on Software, Knowledge and Information Management and Applications Towards Happiness and Sustainable Development, Paro, Bhutan, 25-29 August 2010.

26. Birthal, P.; Jha, A.; Singh, H. Linking Farmers to Markets for High-Value Agricultural Commodities. Agric. Econ. Res. Rev. 2007, 20, 425-439.

27. Ministry of Agriculture (MoA). National Agriculture Policy (NAP). 2018. Available online: www.moa.gov.bd (accessed on 10 August 2021).

28. Department of Agriculture Extension (DAE). National Agriculture Extension Policy (NAEP). 2020. Available online: www.dae. gov.bd (accessed on 10 August 2021).

29. Osmani, A.G.; Hossain, E. Market Participation Decision of Smallholder Farmers And its Determinants in Bangladesh. Ekon. Poljopr. 2015, 62, 163-179.

30. Amare, M.; Mariara, J.; Oostendorp, R.; Pradhan, M. The impact of smallholder farmers' participation in avocado export markets on the labor market, farm yields, sales prices, and incomes in Kenya. Land Use Policy 2019, 88, 104168. [CrossRef]

31. Retsef, L.; Rajan, M.; Singhvi, S.; Zheng, Y. The impact of unifying agricultural wholesale markets on prices and farmers' profitability. Proc. Natl. Acad. Sci. USA 2020, 117, 2366-2371. [CrossRef]

32. Negi, D.S.; Birthal, P.S.; Roy, D.; Khan, M.T. Farmers' choice of market channels and producer prices in India: Role of transportation and communication networks. Food Policy 2018, 81, 106-121. [CrossRef]

33. Karim, R.; Biswas, J. Value Stream Analysis of Vegetable Supply Chain in Bangladesh: A Case Study. Int. J. Manag. Value Supply Chain. 2016, 7, 41-60. [CrossRef]

34. Moahid, M.; Khan, G.D.; Yoshida, Y.; Joshi, N.P.; Maharjan, K.L. Agricultural Credit and Extension Services: Does Their Synergy Augment Farmers' Economic Outcomes? Sustainability 2021, 13, 3758. [CrossRef]

35. Aika, A.; Patience, M.; Victor, A.-S.; Justus, O. Effect of market access provided by farmer organizations on smallholder vegetable farmer's income in Tanzania. Cogent Food Agric. 2021, 4, 1560596. [CrossRef]

36. Makate, C.; Makate, M.; Mutenje, M.; Mango, N.; Siziba, S. Synergistic impacts of agricultural credit and extension on adoption of climate-smart agricultural technologies in southern Africa. Environ. Dev. 2019, 32, 15. [CrossRef]

37. Krug, G. Augmenting propensity score equations to avoid misspecification bias-Evidence from a Monte Carlo simulation. AStA Wirtsch.-Und Soz. Arch. 2017, 11, 205-231. [CrossRef]

38. N'dri, L.M.; Makoto, K. Financial inclusion, mobile money, and individual welfare: The case of Burkina Faso. Telecommun. Policy 2020, 44, 101926. [CrossRef]

39. Zamasiya, B.; Mango, N.; Kefasi, N.; Siziba, S. Determinants of soybean market participation by smallholder farmers in Zimbabwe. J. Dev. Agric. Econ. 2014, 6, 49-58. [CrossRef]

40. Ochieng, D.O.; Veettil, P.C.; Qaim, M. Farmers' preferences for supermarket contracts in Kenya. Food Policy 2017, 68, 100-111. [CrossRef]

41. Mamo, T.; Ameda, T.; Noreen, B. Factors influencing urban and peri-urban dairy producers' participation in milk value addition and volume of milk value added in Welmera Woreda, West Shewa Zone of Oromia Regional State, Ethiopia. Int. J. Livest. Prod. 2014, 5, 165-172. [CrossRef]

42. Maspaitella, M.; Garnevska, E.; Siddique, M.I.; Shadbolt, N. Towards high value markets: A case study of smallholder vegetable farmers in Indonesia. Int. Food Agribus. Manag. Rev. 2018, 21, 73-87. [CrossRef]

43. Jaleta, M.; Gebremedhin, B.; Hoekstra, D. Smallholder Commercialization: Processes, Determinants and Impact; Discussion Paper No. 18; International Livestock Research Institute: Nairobi, Kenya, 2009.

44. Birthal, P.S.; Joshi, P.K.; Gulati, A. Vertical Coordination in High-Value Commodities: Implications for Smallholders; IFPRI MTID Discussion Paper No 85; International Food Research Institute: Washington, DC, USA, 2005.

45. Vakis, R.; Sadoulet, E.; Janvry, A. Measuring Transactions Costs from Observed Behavior: Market Choices in Peru; University of California, Department of Agricultural and Resource Economics: Berkeley, CA, USA, 2003.

46. Abebe, G.K.; Bijman, J.; Royer, A. Are middlemen facilitators or barriers to improve smallholders' welfare in rural economies? Empirical evidence from Ethiopia. J. Rural. Stud. 2016, 43, 203-213. [CrossRef]

47. Xaba, B.; Masuku, M. Factors Affecting the Choice of Marketing Channel by Vegetable Farmers in Swaziland. Sustain. Agric. Res. 2012, 2, 112. [CrossRef]

48. Alene, A.D.; Manyong, V.M.; Omanya, G.; Mignouna, H.D.; Bokanga, M.; Odhiambo, G. Smallholder market participation under transactions costs: Maize supply and fertilizer demand in Kenya. Food Policy 2008, 33, 318-328. [CrossRef]

49. Kassa, T.; Akililu, A.; Tesfaye, G.; Yishak, S. Value chain analysis of banana in Bench Maji and Sheka Zones of Southern Ethiopia. Cogent Food Agric. 2020, 6, 1785103. [CrossRef]

50. Mariano, M.J.; Villano, R.; Fleming, E. Factors influencing farmers' adoption of modern rice technologies and good management practices in the Philippines. Agric. Syst. 2012, 110, 41-53. [CrossRef]

51. Chiv, R.; Nie, F.; Wu, S.; Tum, S. Analysis of Factors Influencing Marketing Channel Choices by Smallholder Farmers: A Case Study of Paddy Product in Wet and Dry Season of Prey Veng Province, Cambodia. J. Sustain. Dev. 2020, 13, 15. [CrossRef]

52. Kassa, G.; Yigezu, E.; Alemayehu, D. Determinants of smallholder market participation among banana growers in bench Maji Zone, Southwest Ethiopia. Int. J. Agric. Policy Res. 2017, 5, 169-177. [CrossRef] 
53. McNamara, P.E.; Tata, J.S. Principles of Designing and Implementing Agricultural Extension Programs for Reducing Post-harvest Loss. Agriculture 2015, 5, 1035-1046. [CrossRef]

54. Shiferaw, B.; Hellin, J.; Muricho, G. Improving market access and agricultural productivity growth in Africa: What role for producer organizations and collective action institutions? Food Secur. 2011, 3, 475-489. [CrossRef]

55. Benedek, Z.; Ferto, I.; Molnár, A. Off to market: But which one? Understanding the participation of small-scale farmers in short food supply chains-A Hungarian case study. Agric. Hum. Values 2018, 35, 383-398. [CrossRef]

56. Bindu, S.; Chigusiwa, L. Examining the Sources of Smallholder Horticultural Farmers Exclusion from Formal Urban Markets in Zimbabwe: The Case of Chihota Communal Areas. Int. J. Econ. Res. 2013, 4, 1-12.

57. Panda, R.K.; Sreekumar. Marketing Channel Choice and Marketing Efficiency Assessment in Agribusiness. J. Int. Food Agribus. Mark. 2012, 24, 213-230. [CrossRef]

58. Jari, B.; Fraser, G.C.G. An analysis of institutional and technical factors influencing agricultural marketing amongst smallholder farmers in the Kat River Valley, Eastern Cape Province, South Africa. Afr. J. Agric. Res. 2009, 4, 1129-1137.

59. Mukarumbwa, P.; Mushunje, A.; Taruvinga, A.; Babatope, A.; Ngarava, S. Analysis of factors that influence market channel choice of smallholder vegetable farmers in Mashonaland east province of Zimbabwe. Int. J. Dev. Sustain. 2018, 7, 734-754.

60. Caliendo, M.; Kopeinig, S. Some Practical Guidance for the Implementation of Propensity Score Matching. J. Econ. Surv. 2008, 22, 31-72. [CrossRef] 